\title{
The T'ang Code
}

VOLUME II: SPECIFIC ARTICLES

Translated, with an introduction, by Wallace Johnson

"The translation is remarkably faithful and the translator demonstrates a high degree of famillarity with Western legal terminology."

-Early Medieval China
This is the second and final volume of the annotated translation of a seminal Chinese legal text. The T'ang Code, written in 653 A.D., Is the most important legal text in East Asian history. Not only is it Chlna's earliest law code to survive in its entirety, influencing all subsequent Chinese law, but it has also served as a model for codes of law In other East Asian countries, Including Japan, Korea, and Vletnam. This is the only translation of the T'ang code into a Western language. Priceton Library of Asian Therulations Cloth 160.00 ISBN 0-691-02579.7

\section{Princeton University Press FROM BOOKSELLERS OR PHONE (1-243) 779777 U.K. • (800) $777-4726$ U.S. HTTP://PUP.PRNCETON.EDU}

\section{THE BRITISH INSTITUTE OF INTERNATIONAL AND COMPARATIVE LAW and SPTL PUBLIC INTERNATIONAL LAW SUBJECT GROUP}

\section{Eighth Conference on Theory and International Law \\ INTERNATIONAL LAW IN DOMESTIC COURTS: BEYOND MONISM AND DUALISM?}

Thursday, 26 March 1998. $10.00-5.00$

Price: Individual £35/Student Member $£ 10$

For further dotails please contuct Louive Saunders, The Brithh Imettute of Intermational and Comparative Law. Chartos Clore House, 17 Rusuel Square. Loodon WC1B SDR. Ted: +44(0)171 6365802 . Fax: +44(0)171 3232016 


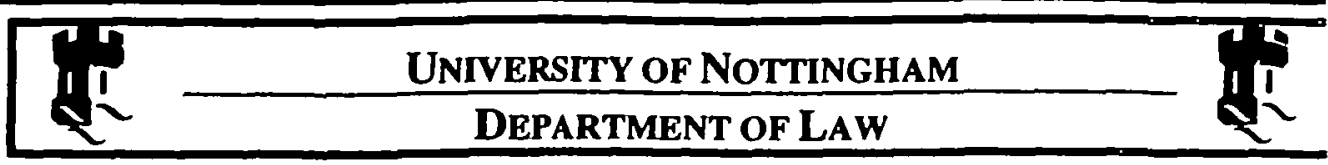

- RATED EXCELLENT FOR TS TEACHING AND A WARDED TOP GRADE S FOR ITS RESEARCH -

\title{
Postgraduate Law Programmes
}

\section{Taught Master of LaWS (LL.M.) ONe-Year Programme} featuring over thinty options tangh by seminar wethod and leading to the award of one of the following specialisations:

LL.M. IN PUBLIC INTERNATIONAL LAW

LL.M. IN HUMAN RIGHTS LAW

LL.M. IN INTERNATIONAL COMMERCIAL LAW

LL.M. IN EUROPEAN LAW

LL.M. IN ENVIRONMENTAL LAW

LL.M. IN INTERNATIONAL LAW AND ARMED CONFLICT

\author{
ResearCh Programmes \\ offered under expert supervision and wh excellent research facilties leading to: \\ MASTER OF PHILOSOPHY (M.PHIL) \\ DOCTOR OF PHILOSOPHY (PH.D.)
}

\section{JOINT MaSter OF LA WS (LL.M.) ONE-YEAR PROGRAMME from Academic Year 1998-99, the Department of Law intends to offer this Joint Programme with: \\ UNIVERSTTY OF BIELEFELD \\ UNIVERSITY OF NATAL \\ NATHONAL UNIVERSITY OF SINGAPORE \\ UNIVERSITY OF MAASTRICHT}

POSTGRADUATE LAW PROSPECTUS AVAILABLE NOW FROM:

Professor David J. Harris

DEPARTMENT OF LAW. UNIVERSTTY OF NOTTINGHAM. UNIVERSITY PARK.

NOTTINGHAM, NG7 2RD, UNITED KINGDOM.

Telephome: + 44 (115) 9515694 - Foc simile: + 44 (115) 9515696

(PLEASE MARK ENVELOPE LLM OR RESEARCH AS APPROPRIATE)

Electronic Mail Communications:

LLMPHDENOTTINGHAM.AC.UK

Visil Our Home Page At:

HTTP-J/WWW.NOTT.AC.UK/

Applications To Be Received By 31 May 1998

The University of Nottingham is a research-led institution of international excellence which provides the highest quality learning environment. 


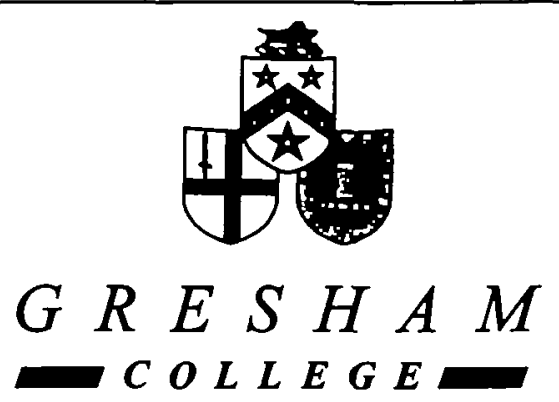

Founded 1597

\section{APPOINTMENT OF GRESHAM PROFESSOR OF LAW}

The Council of Gresham College invites applications from women and men who wish to be considered for appointmeat as Gresham Professor in the above discipline, or nominations of candidates of appropriate atanding who might be approached. The appointment, which is part-time, will take effect in September 1997.

Gresham College was extablished in 1597 under the Will of Sir Thoma Gresham as an independent educational institution. It supports programmes of free public lectures in the disciplines provided for under the terms of Gresham's bequest and seets to interpret the 'new learning' of Gresham's day in contemporary terms. It reeks to involve those who live and wort in the City of London in intellectual debate, and is particularty interested in candidates who can bring to a general audience an awareness of the progress in and significance of thoir field.

The College would be interested in candidates from any branch of the law able to offer a weries of lectures on topies of current interest to a general audience. The appointment is for throe years but exceptionally the College would be prepared to consider a shorter appointment for persons whose prectice or professional commitments make a longer tenure difficult.

The principal obligation for all Professonthips is to offer six lectures each year. Opportunities exist for support to be given to research activities in which the Profeser is involved. An annual foo of $£ 3,750$ (inc VAT) is payable.

Please send for forther particulars to

The Provost (Dopt ICLQ), Grestam Colloge

Bamard's Inn Hall, Holborn, London ECIN 2HH

Tel: 01718310575 . Fax: 01718315208

http://wow.gresham .ac.uk

Closhe date for applleations ts

Frlday 27 February 1998

Gresham Colloge Trust is a company limited by guarantoe regiatered

in England and Wales. Regiviered Charity No: 1039962 


\title{
International and Comparative Law Quarterly
}

(incorporating the Quarterly of the Society of Comparative Legislation and International Law and the Transactions of the Grotius Society)

\section{BOARD OF EDITORS}

General Editor: ALAN BOYLE

Assistant General Editor: JoE MACDONALd HILL

\author{
JOHN BELI \\ P. B. CARTER \\ LAWRENCE COLLINS \\ HAZEL FoX \\ Piers Gardner \\ JOHN A. UsHER
}

